\title{
Career Aspirations as Part of Vocational Guidance for Persons with Hearing Impairment
}

\section{Ivana Horváthová}

\begin{abstract}
Currently, there are new trends and possibilities on the labour market, which has an effect on the ideas of today's students, both intact and those with hearing impairment. In thinking about their future careers, students naturally decide based on their values, self-confidence or ever various features of sub-cultures, which also include persons with hearing impairment. This fact can significantly affect the aspiration of students with hearing impairment. The paper attempts to identify the degree of influence of elementary schools, teachers and other factors on career aspirations in students with hearing impairment in consideration of their disability. In this case, career aspirations are considered part of vocational guidance and preparation for future careers. The data were obtained in the framework of the following project: "Teaching Staff as a Key Factor in Inclusive Education", which was conducted at the Faculty of Education, Palacký University Olomouc under Ref. No. PdF_2016_026 and co-funded by a specific university research scheme.
\end{abstract}

Keywords: Career aspirations, vocational guidance, person with hearing impairment, teacher. 


\title{
Kariérna aspiracia ako súčast' odborného poradenstva pre osoby so sluchovým postihnutím
}

\begin{abstract}
Abstrakt
V súčasnom dianí sa objavujú nové trendy a možnosti v uplatňovaní sa na trhu prácu a tomu podliehajú aj predstavy dnešných žiakov ako intaktných, tak aj žiakov so sluchovým postihnutím. Pri premýšlaní o budúcom povolaní sa žiak prirodzene rozhoduje na základe hodnot', sebadôvery či dokonca znakoch subkultúry do ktorej patria aj osoby so sluchovým postihnutím. Práve tento fakt môže výrazne ovplyvňovat’ ašpirácie žiakov so sluchovým postihnutím. Článok sa zaoberá identifikovaním miery vplyvu základnej školy, pedagógov a iných faktorov na profesijné ašpirácie u žiakov so sluchovým postihnutím s prihliadnutím na ich postihnutie. Profesijné ašpirácie v tomto prípade berieme ako súčast' profesijnej orientácie a prípravu na budúce povolanie. Dáta boli získané za podpory porojektu „Pedagogičtí pracovníci jako klíčový faktor inkluzívního vzdělávaní“, ktorý bol riešený na Pedagogické fakulte Univerzity Palackého v Olomouci pod číslem PdF_2016_026, za podpory prostriedkov specifického vysokoškolského výskumu.
\end{abstract}

Klúčové slová: Profesijné ašpirácie, profesijná orientácia, osoba so sluchovým postihnutím, pedagóg.

\section{Introduction}

Vocational guidance is based on the aspirations of each individual. Aspirations express what a person would like to achieve. The gap between aspirations and the actual level is relatively stable, but largely depends on the degree of self-confidence, characteristics of the group to which an individual belongs, the nature of the society and the qualities of the relevant subculture as well as the whole culture (Velký sociologický slovník, 1996).

The term aspiration comes from the Latin word aspirare, which means to contribute, to strive for something. Aspiration is a deliberate action with a specific purpose. Aspirations are closely linked with external and internal aspects such as for example personality traits of an individual, value orientation, predispositions or culture.

It is something that a person hopes to do and achieve. It is also understood as a desire for something. Aspiration represents a degree of demands placed in the present or in the future on oneself, one's own self-actualization and self-development, one's own position in personal life and in the society (Boroš, 1997).

According to Trice and Hughes (1995), career aspirations are also affected by parents' jobs and their satisfaction at work. Research suggests that students who see their parents' satisfaction at work have two to three times higher career aspirations compared 
with those who believe that their parents are dissatisfied at work. There are also other social conditions that affect career aspirations. Another issue investigated by the authors was the difference between fathers' and mother' influence on career aspirations. They concluded that career aspirations in boys and girls were consistent with mothers' careers; this was not confirmed in the case of fathers' careers.

As was mentioned above, there are more aspects that influence career aspirations in students. They are as follows: student's gender, parents' career, type of school studied, size of the student's place of residence, computer skills, scientific knowledge, household equipment.

In his research, Katrňák (2006, p. 183) added other factors such as parents'academic degree, cultural capital of the family, availability of educational resources and the child's cognitive abilities.

\section{Aspiration level}

A part of career aspirations is the aspiration level, which represents all expectations and demands concerning one's own future performance. Aspirations reflect the desired performance and therefore might have a motivating potential. This level is different in each person and also varies by individual activities (Buchtová et al., 2003).

A low aspiration level inhibits activity and attention, decreases interest in performance, and weakens the ability to overcome obstacles. Inadequately high aspirations might cause frequent failures caused by an inability to achieve the set objectives, which might lead to disappointment and disgust. On the other hand, they can also induce undesirable egocentrism, excessive efforts to excel, overestimation of oneself, as well as inconsiderateness in enforcing oneself (Klindová, 1985).

According to Janoušek (2006), the functioning of the aspiration level has four stages:

- During the first stage the initial reference performance is achieved;

- During the second stage, based on the experience with one's own performance in the first attempt, the person estimates the performance level in the next attempt the aspiration level for the next performance is defined;

- During the third stage the next attempt is performed;

- During the fourth stage the person reacts to the new performance with satisfaction or dissatisfaction based on self-assessment.

In the Czech Republic, a curriculum was developed for a separate course called Career Choice (Horská, Zemánková, 2001), which is, in a limited extent, used in practice. The objective of the course is to support the students' career aspirations and a responsible attitude in selecting their careers. 


\section{Vocational guidance of students with hearing impairment}

In the last grades of elementary school students start to choose their future careers, which is the time for vocational guidance and career aspirations. Choosing a career by students with hearing impairment is more difficult because the specifics of their disability need to be considered.

Despite the new and perspective opportunities on the labour market there are still numerous factors that influence career choice in students with hearing impairment. These factors have a considerable effect on the students' ideas and aspirations, their professional preparation and eventually their chances on the labour market. Therefore, the ideas of persons with hearing impairment are not linked with their personal aspirations but rather to adapting to the limitations caused by their disability. These include not only a limited selection of further education, both in terms of practical availability and selection of courses in special schools, but also an insufficient number of jobs suitable for persons with hearing impairment. These persons' interests and motivations are seldom taken into account.

\subsection{Aspects that influence vocational guidance}

The most significant aspects that influence students' decisions concerning their career choice include the family, educational institution represented by the class teacher, educational counsellor, as well as classmates and friends. In general, students' opinions and ideas are influenced by a narrower and wider social environment. The effect of the family, small peer groups, teachers and various personalities on the life of an individual depends on the possibilities and requirements of the social environment (Čáp, 1979).

This is confirmed by various studies focused on sociological issues. Walterová, Greger and Novotná (2009) performed a questionnaire-based research aimed at the influence of various actors on vocational guidance. They asked both parents and students. The research study suggests that the greatest influence on career decisions is attributed to students themselves followed by their parents. As far as parents are concerned, a greater influence is attributed to mothers. Other influences included teachers, friends and counsellors at various institutions; siblings came last. The responses of parents were almost identical. Parents were followed by friends, teachers, siblings and counsellors. However, the effect of the family does not change in any way from the perspective of students or parents.

These results are also confirmed by other studies performed by Kniveton in the UK. Similar studies were also performed in the Czech Republic by Friedmann, Hlad'o, Knoll or in Slovakia by Vendel, who focused on the resources that students use to find out information about further study. 
The causes of preferring parents' opinions are generally known. For the parents it is usually financially demanding if their child studies far from home or if the child commutes several kilometres to school; therefore, they choose a school close to their place of residence. Families who have children with hearing impairment also consider teaching methods and communication in school. School selection also depends on the culture of persons with hearing impairment. Fields of study designed for students with hearing impairment are preferred by those parents who also have hearing impairment.

Another significant aspect that influences the selection of a particular study field is the teacher. According to Fontana (2010), every teacher is also an educational counsellor. This applies especially to class teachers, who are involved in career counselling and organize and control vocational guidance in their class. They are also involved in providing information in the process of career preparation. They also provide individual consultations to parents as well as students. On the basis of students' plans they help develop their career desires and objectives.

To better understand students' behaviour, teachers must be familiar with the students' families. The family has a considerable influence on the student and sometimes the teacher is unable to affect their behaviour, relationships to oneself and other people, or their attitude to their future career. For teachers it is impossible to improve students academic performance without cooperation with the parents. They need to be active and encourage their children for study (Hartl, 1999).

If teachers are familiar with students' backgrounds, they become appropriate counsellors in the process selecting a secondary school. Another significant aspect in providing information is the teacher-student interaction. This requires mutual trust, a sense of responsibility and positive relationships (Helus, 1982). If there is no teacher-student feedback, the teacher loses control over the situation.

If these preconditions for a quality relationship are achieved, students will likely identify with the teacher. This leads to a relationship based on trust, which is essential in the process of selecting a secondary school. The teacher must consider the student's interests and opinions, and possibilities of the family. It is also necessary to take into account the abilities and possibilities of the student. These should be neither overestimated nor underestimated. This requires a long-term educational activity on the part of the teacher, trust, ability to give advice, and knowledge of the region, available schools and academic requirements. This also places considerable requirements on the teacher's qualification and personality.

Despite these facts, in the area of career counselling the teacher's guidance is sought for sporadically, especially by students with special educational needs (Friedmann, 2011). The research suggested that only $1 \%$ of students were influenced by the teacher. We believe this can result from poor awareness of students concerning career counselling provided by teachers, or students' distrust. 


\section{Description of the research}

\subsection{Objective and Methodology}

The main objective of the present study is to identify the effect of external factors on career aspirations in students with hearing impairment.

The main approach is a quantitative analysis, the objective of which is to identify the current career aspirations in students with hearing impairment. The research instruments used to achieve the objective of the study and to verify the research hypotheses was a questionnaire.

\subsection{Research sample}

The research sample consisted of 48 students of schools designed for students with hearing impairment in the Czech Republic. For the purposes of the present paper the authors randomly selected the following schools:

- Secondary, elementary and nursery school for the hearing impaired, Olomouc,

- Nursery school and Elementary school for the hearing impaired, Brno,

- Elementary school and Nursery school for the hearing impaired, Plzeň

- Elementary school and Nursery school for the hearing impaired, Hradec Králové

- Secondary school, Elementary school and Nursery school for the hearing impaired, Radlice - Prague 5.

\section{Students with hearing impairment}

The target group of students with hearing impairment was selected on the basis of their career aspirations that influence their selection of future education and competitiveness on the labour market. According to Vágnerová (2005), the crucial age group is midschool age to the beginning of pubescence. During this age, maturing takes place. In the context of the educational system, this includes students in grade eight and nine of elementary school. Kuric (2000) claims that these individuals start to think about problems they had not dealt with before. They try to structure their future, think about their future education and career, and form their opinions about the world.

\subsection{Data collection methods for the quantitative part of the research}

The suitability of the questionnaire was first verified on a small sample of students with hearing impairment and only then was applied to the whole research sample. 
The quantitative part of the research was based on an anonymous questionnaire of own design. The questionnaire included open-ended (non-structured), closed (structured) and semi-closed (semi-structured) items.

\section{Quantitative data analysis}

For the purposes of a quantitative analysis of the questionnaire-based data, the methods specified below were used.

Prior to the analysis the questionnaires were sorted. The analysis also included questionnaires with unanswered items up to $20 \%$ of missing answers. Any other questionnaires were excluded from the research. The data from the questionnaires were statistically processed. The data were transferred from the questionnaires to an electronic form using Microsoft Excel.

Statistical hypotheses were tested at a level of statistical significance of $a=0.05$. For each statistical test the achieved level of significance was calculated ( $p$-value). The zero hypothesis was rejected if the achieved level of significance was lower than the predetermined level. The calculations were performed using Microsoft Excel 2010.

For the purposes of statistical processing the data were stored in a Microsoft Office Excel 2010 spreadsheet and checked for correctness. For the descriptive part of the analysis the author used basic mathematical characteristics, i.e. frequency, relative frequency, and arithmetic mean. Statistical testing of the hypotheses was performed by the Chi-square test of independence for a contingency table in order to verify the significance of the predetermined distribution of probability of quantities.

\section{Questionnaire distribution and return rate}

The questionnaire was distributed between April and June 2016. For the purposes of the research a total of 48 questionnaires were produced and distributed to students with hearing impairment in grades 8 and 9 of elementary school.

Socio-demographic characteristics of the respondents

The research involved 20 boys ( $42 \%$ ) and 28 girls (57\%). Another socio-demographic indicator of both groups of respondents was their age. The research involved 31 respondents (64.6\%) aged $14-15$ years, 15 respondents (31.2\%) aged 16-17 years, and 1 respondent $(2.1 \%)$ aged 18 years. Of the total number, one respondent did not answer.

Another important aspect for the assessment of the hypotheses was the type of hearing impairment. Of the total number of participants $(n=48), 18$ students $(37.5 \%)$ were hard of hearing, 22 students ( $45.8 \%$ ) were deaf, and 2 students ( $4.2 \%)$ were unable to answer. 6 respondents (12.5\%) did not answer. 


\subsection{Results of the research study}

According the authors' assumption, the selection of study fields is often performed by parents; therefore the following question focuses on whether the respondents consulted the selection of a secondary school with their parents. Both girls and boys consulted the selection of a secondary school with their parents. As the table suggests, the second most frequent response was 'close to the place of residence' closely followed by the influence of teachers on aspirations. A surprising fact is that in girls this influence is stronger. However, the authors did not examine the effect of the teachers' gender on the students' choice.

Table 1

Preferences of secondary school selection

\begin{tabular}{|l|c|c|c|c|c|c|c|}
\hline \multicolumn{2}{|l|}{ According to which criteria did you choose secondary school? } \\
\hline Criteria & a & b & c & d & e & f & Total \\
\hline Boys & 3 & 1 & 7 & 4 & 0 & 5 & 20 \\
\hline Girls & 8 & 5 & 6 & 2 & 7 & 0 & 28 \\
\hline Total & 11 & 6 & 13 & 6 & 7 & 5 & 48 \\
\hline
\end{tabular}

Legend: $\mathrm{a}$ - What I am interested in; $\mathrm{b}$ - What the school/teacher advised me; $\mathrm{c}$ - What my parents chose for me; $\mathrm{d}$ - What my friends chose; $\mathrm{e}-\mathrm{School}$ close to the place where I live; $f$ - Other

Table 2

Assistance in secondary school selection

\begin{tabular}{|l|c|c|c|c|c|}
\hline \multicolumn{6}{|l|}{ Who helped you in selecting a secondary school? } \\
\hline & Parents & Friends & Teacher/school & Other & Total \\
\cline { 2 - 7 } & $\mathbf{n}$ & $\mathbf{n}$ & $\mathbf{n}$ & $\mathbf{n}$ & $\mathbf{n}$ \\
\hline Students & 21 & 10 & 15 & 2 & 48 \\
\hline
\end{tabular}

The previous table shows a clear influence of parents. However, the second most frequent factor in selecting a secondary school is the teacher. The next question focused on the provision of information. As far as the form of information is concerned, the most frequent was verbal information provided by the class teacher. This form was followed by information meetings and visits to the labour office. In one case, students with hearing impairment had an opportunity to meet a local employer who offered them a job provided that they complete the required field of study. The extent to which this information is distorted is questionable. Headteachers (as suggested in unrecorded interviews) try to keep their students in associated schools and therefore this informa- 
tion might be influenced by this fact. Obviously, this is caused by the system of funding, which is currently a hot issue in every school.

Another criterion in secondary school selection was choosing between a mainstream secondary school and a secondary school designed for students with hearing impairment.

Table 3

Preference of study fields for individuals with hearing impairment

\begin{tabular}{|l|c|c|c|}
\hline \multicolumn{2}{|l|}{ Did you select a secondary school that offers study fields for the hearing impaired? } \\
\hline & YES & N0 & Total \\
\cline { 2 - 4 } & $\mathbf{n}$ & $\mathbf{n}$ & $\mathbf{n}$ \\
\hline Deaf & 12 & 8 & 20 \\
\hline Hard of hearing & 12 & 16 & 28 \\
\hline Total & 30 & 18 & 48 \\
\hline
\end{tabular}

As was assumed, hard of hearing individuals do not prefer schools for the hearing impaired unlike deaf individuals. However, in both groups this was confirmed by a small difference in their responses.

\section{Conclusion and Discussion}

It is difficult to precisely define the factors and aspirations that affect the selection concerning future careers and future education made in elementary school. The reason is a low number of relevant empirical studies that would focus on this aspect in students with hearing impairment.

The authors of the present paper conducted a literary review in order to find articles on factors influencing secondary school selection. However, these articles are of a general focus on persons with health disability and all information is generalized for all types of health disability. Due to the specific nature of perception and personality of individuals with hearing impairment, the results of the present study were not compared with these research papers.

The author found a study by Cherry \& Gear (1981) Young people's perceptions of their vocational guidance needs: I. Priorities and pre-occupations, British Journal of Guidance \& Counselling, conducted in the UK in 1981. The study included 1,712 students in the third, fourth and fifth years of secondary education at 20 comprehensive schools. Their task was to complete a questionnaire about the priorities they gave to different aspects of vocational choice and preparation. The research focused on intact students. 
The results of the study confirms one of the conclusions of the present paper that parents have a considerable effect on secondary school selection and career choice. An interesting finding in the study by Cherry \& Gear (1981) is that students who had completed school gave more priority to their own preferences than their parents' and teachers' compared with those who were still studying (the distribution of answers was not specified).

A research study performed by Foskett and Hesketh (1997) in an English-speaking environment assumed that the greatest influence would be represented by parents. However, this was confirmed by only $22 \%$ of respondents. In the present study, many respondents indicated parents as those who help in selecting a secondary school. Parents are not only decision-makers, i.e. initiators of the decision-making process, but also the primary source of help and advice.

The study mentioned above also included answers suggesting friends' influence on secondary school selection. In the present research the effect of friends was also suggested. It should be mentioned again that the study included students without disability, which had an effect on their responses. We believe that also for this reason students with hearing impairment assign greater importance to their friends' opinions. Regarding the fact that the participants of the present study were individuals with hearing impairment, one of the options was 'school close to the place of residence'. We assumed that in persons with any type of disability this would be one of the reasons for selecting a secondary school.

However, we should not forget the effect of teachers, which is apparently very influential. Therefore, we believe that the teacher-school cooperation is of great importance. A research study by Bartoňová (2011) dealt with vocational guidance in students with specific learning disorders. One of the areas focused on the influence on students' career choice. Again, this study confirmed the greatest influence of parents, followed by friends, and finally educational counsellors, class teachers and employees of educational and psychological counselling centres with an equal share.

A limitation concerning the information gathered might be the fact that we did not examine whether the individual concerned is the first child or whether the family has more children with hearing impairment. We became aware of this fact in the course of the research and we believe that this is an important aspect because it might be expected that the decision-making process will be different in the case of the first child.

The influence of parents is a crucial one. Recently, it has even gained importance. The question that remains and that might be the starting point of subsequent research is to what extent students' decision-making is autonomous in this context. This fact is also important because in the decision-making process, parents and children follow different objectives, have different ideas about the future, and use different strategies in terms of obtaining information. The link between these to 'worlds' could be the teacher, who meets both the parents and the students. The question is the reliability of the teacher in this capacity. 
As suggested by Horváthová in her research study (2011), the causes of inappropriate secondary school selection might be as follows:

- Insufficient information provided by schools,

- Influencing of the child by parents and overestimation of his/her abilities,

- Students are not aware of possible difficulties that could occur in relation to their career choice and their impairment,

- Students choose their career based on a single factor and do not consider other significant aspects of the career selected.

With respect to the type of impairment (hearing impairment), one of the criteria of school selection was the type of school. We assumed that deaf individuals would prefer study fields for the hearing impaired, which has not been confirmed by the results of the present study. This is also confirmed by the results of a research study by Hudáková (2014), who emphasised a decreasing trend in special education, while the number of integrated students with hearing impairment remained constant. This statistical indicator reflects the results from 2003 to 2013. However, in the research the author focused solely on students with severe hearing impairment. This means that the number of students in mainstream schools is much higher. Similarly, not all students in mainstream schools are individually integrated. Another aspect that needs to be considered is that currently fewer children are born. A different result was brought by the qualitative part of the present research, where all respondents selected study fields designed for the hearing impaired, but this finding cannot be generalized because this was only a small research sample of interviewees.

At present, there is an abundance of research studies that analyse the factors influencing career choice; however, none of them focuses on individuals with hearing impairment. Most current projects and research studies focus on employer awareness.

\section{References}

Boroš, J. (1995). Motivácia a emocionalita člověka. Bratislava: Odkaz.

Donnelly, V. \& Kyriazopoulou, M. (2014). Organizace opatrení na podporu inkluzivního vzdělávání. European Agency for Special Needs and Inclusive Education. (Electronic version) [online]. [cited 2014-05-25]. Retrieved from: https://www.european-agency.org/sites/default/files/ OoPSummaryReport_CS.pdf.

Foskett, N. H., \& Hesketh, A. J. (July 07, 2006). Constructing Choice in Contiguous and Parallel Markets: institutional and school leavers' responses to the new post-16 marketplace. Oxford Review of Education, 23, 3, 299-319.

Groma, M. (2012). Kariérové poradenstvo a možnosti facilitácie kariérového vývinu nepočujúcich. Bratislava: Univerzita Komenského.

Horská, V. \& Zemánková, H., et al. (2005). Volba povolání - metodická př́ručka pro učitele. Most: Hněvín. 
Horváthová, I. (2011). Problematika profesijnej ašpirácie u žiakov základných škôl so sluchovým postihnutím. In Poláchová Vaštatková, J. Bačíková, A. (Eds.) Aktuální problémy pedagogiky ve výzkumech studentů doktorských studijních programů. VIII. Olomouc: UP.

Hudáková, A. (2014). Počet žáků se sluchovým postižením v integraci a inkluzi. [unpublished]

Cherry, N., \& Gear, R. (January 01, 1987). Young people's perceptions of their vocational guidance needs: I. Priorities and pre-occupations. British Journal of Guidance and Counselling, 15, $1,59-71$.

Janoušek, J. (2006). Aspirační úroveň, výkonový motiv, a vnímané sebeuplatnění jako psychologické faktory výkonnosti ve společenských podmínkách. Pražské sociálně vědní studie - Psychologická řada PSY-005. Praha: FSV UK.

Katrňák, T. 2006. Faktory podminující vzdělanostní aspirace žáku devátých tříd základních škol v České republice. In Matějů, P., Straková, J., \& Basl, J. (2006). (Ne)rovné šance na vzdělání: Vzdělanostní nerovnosti v České republice. Praha: Academia.

Klindová, L'. \& Rybárová, E. (1985). Psychológia II: Vývinová psychológia pre 2. ročník stredných pedagogických škôl. Bratislava: SPN.

Kuric, J. (2000). Ontogenetická psychologie. Brno: CERM.

Přinosilová, D. (2004). Vybrané okruhy speciálně pedagogické diagnostiky a její využití v praxi speciální pedagogiky. Brno: MU.

Velký sociologický slovník. (1996). Praha: Karolinum.

Šedivá, Z. (2006). Psychologie sluchově postižených ve školní praxi. Praha: Septima.

Trice, A. D., Hughes, M. A., Odom, C., Woods, K. \& McClellan, N. C. (1995), The Origins of Children's Career Aspirations: IV. Testing Hypotheses from Four Theories. The Career Development Quarterly, 43: 307-322, doi:10.1002/j.2161-0045.1995.tb00436.x.

Vágnerová, M. (2005). Vývojová psychologie: I. Dětství a dospívání. Praha: Karolinum.

Vašutová, M. (2005). Pedagogické a psychologické problémy dětství a dospívání. Ostrava: Ostravská univerzita, Filozofická fakulta.

\section{Contact:}

Mgr. Ivana Horváthová, Ph.D.

Institute of Special Education Studies

Faculty of Education, Palacký University in Olomouc

Žižkovo nám. 5, 77140 Olomouc, Czech Republic

E-mail: horvathova-ivana@seznam.cz

Mgr. Ivana Horváthová, Ph.D. has completed Master's degree at Comenius University in Bratislava (Slovak Republic), Department of Special Education - focusing on Deaf Studies and pre-school education. Then she studied Ph.D. study programme with a focus on special needs education at Palacky University in Olomouc, where she still acts as a senior lecturer at the Institute of Special Education Studies. She also works as a study assistant for students with special needs in the Centre of Support for Students with Special Needs at Palacky University. She has experience in consulting and direct work with people with special needs. She has led or was part of a team of ESF or Palacky University projects. She has attended many national and international conferences and participated on domestic and foreign publications. 